\title{
Book Review: Revealing the Oppressions on Women and People by Arabic Language and Writing
}

\author{
So-Yeon Chung1)
}

\begin{abstract}
This paper is the review for the book of Fatima Mernissi, "The Forgotten Queens of Islam". It is published in French in 1990, in English in 1993, and translated in Korean in 2016. The writer is the representative scholar among Islamic feminists. She wrote on 20 queens as religious and political leader in Islamic world. Some queens are revealed in this book for the first time. This book is more remarkable how the present Islamic writer's view is on the queens in middle age, and how to reveal the women and people's oppression by the detailed analysis on Arabic language. Though there is some bias view, this book is practical and brave work to grasp the political problem sharply hidden by religion.
\end{abstract}

Keywords : The forgotten queens of islam, Islam, Queen, Muslim, Islamic feminism, Fatima mernissi

\section{Introduction}

『The Forgotten Queens of Islam』 is a thirty-year-old book written by an author Fatima Mernissi who left the world in 2015. It was published in French in 1990, in English since 1993[1], and the latest in a Korean version that has not yet been published in a year[2]. The combination of the two words 'Islam' and 'Queen' makes us suspect how challenging this book is. This book deals with twenty queens of the Muslim world from the 11th to the 17th centuries.

Korea did not have a queen at this time. There were three queens in the 7th and 9th centuries, the Silla period, but this is 'Ancient Times'. It is difficult to see the Queen in the Confucian-Chinese civilization, while in the Middle Ages, which is characterized by the common written language and the common religion[3]. The fact that there were so many queens in the Muslim-Arab civilization in the Middle Ages is how much more serious a matter of gender equality - under the premise that dividing power in half is equality - in Korea.

Let's look the book briefly. First of all, faithful to the title of the book, the author is looking

Received(March 24, 2018), Review Result(1st: April 2, 2018, 2nd: April 27, 2018), Accepted(May 4, 2018)

${ }^{1}$ Dept. of Korean Education, Ewha Womans Univ., Seodaemun-gu, Seoul, 03760, Korea

email: chong33@ewha.ac.kr 
closely at the Muslim Queens. Chapter 6 of this book provides a detailed description of the Islamic female rulers of the two Turks, six Mongols, seven Maldives and seven Indonesian women. The Jarya(female slavery), who was the head of power even though he could not be a Caliph(spiritual leader), are introduced in Chapters 3 and 4 in more detail. What is more noticeable is that there are three more 'Arab' queens who have been a Caliph! This is detailed in Chapters 7, 8, and 9 of this book.

The author said that the presence of the queen of the Islamic world was more difficult because of the role of the religious leader, Caliph. There is no feminine noun of the word caliph. Nevertheless, it is surprising that there were the queens being the Islamic ruler who was satisfied with two conditions, the direct execution of the Sunday worship sermon Kutva and the coinage of his name engraved coins.

This spiritual leader, Caliph, must be Arab and male. It has been constantly challenging the former in the history of the Islamic world, but the latter has not. In this context, the author 's attempt to find a female Caliph shows the academic attitude and learn mind beyond just providing information of the female Caliphs. In this regard, I would like to applaud the author for showing that writing is a movement towards freedom.

Of course, this book is not the first to reveal the queens in the Muslim world. The fifteen sultana (female noun of the male noun "sultan" referring to the kings) have already been found through previous researches, but this book has found more than that, and has shown the movement of women liberation by writing, which is the liberation of words - 'Harara', which means 'liberation of the word', is to liberate the meaning by making it a word (p.30). Furthermore, it is worth noting that this book links women's discrimination with democracy by relating the problem between men and women to upper class and low people. It is a new challenge for readers after reading this book to compare of how male scholars dealt with the queen of Islam to the book written by a female author .

Therefore, the issue to be noticed in this book is not just how the twenty queens appeared in the Muslim world, how it came about and what it did. That is a very basic purpose of this book. And the queens of fifteen has already been revealed by some historians before this book. About informations on Islam queens, this book seems to have been done well enough and it deeply examines in detail on the Arab queens in addition to the 15 queens found by the old historians. Rather, it should be noted in what way the modern Islamic female writer looks at the emergence and rule of the queen that existed in medieval Islam, and what language and writing this vision is revealing.

Rather, it should be noted in what way the modern Islamic female writer looks at the 
emergence and rule of the queen that existed in medieval Islam, and what language and writing this vision is revealing.

This is a problem related to Islamic feminism that emerged in the latter half of the 20th century. Islamic feminism is a series of reinterpretations of Islamic texts that seek to the basis for equality of men and women from Koran as conservative male scholars approach women in their interpretation of Koran's interpretation[4]. Morocco's female sociologist, author Fatima Mernissi, is famous as a major thinker of Islamic feminism and won the Asturias and Erasmus awards. The point of reading this book can be summarized as follows.

First, who was the queen, how did she come to the Middle Ages and what did she do?

Second, what perspective does a female author in the Muslim world to the emergence and rule of a medieval Islamic queen compared to other male historians?

Third, what about language and writing that reveal this view?

As mentioned above, the first point is the main content of this book and it is surfaced. However, the second and third problems are hidden rather than surfaced, and scattered sporadically, so the reader must find out. Above all, it is the whole view of the book that the author especially emphasizes, so it should pay more attention. Therefore, this article focuses on second and third problems.

2. Medieval Islamic queens from the perspective of a modern Islamic female author

Particularly, the three chapters elaborate on the routes they took to approach the supreme power pushing the envelope of Harem (or Harim), the space reserved for women in the houses of Muslim families. Also, chapters 6, 7 and 8 explicate the cases of daughters or mothers in royal families who became Sultanas, or supreme rulers. In brief, Muslim women were able to enter the world of power when they were tradeable slaves or had royal spouses, sons, fathers and siblings.

Nonetheless, ordinary men and women may perceive such a route to power as another discrimination. That is why the author writes "All discourses on women in the Arab world are congruent with those on the development and status of individuals in the society" (p. 316). In that regard, the author captures why the issue of discrimination against women in the Islamic world is linked to that of the grass roots and of democracy, which is a noteworthy point of 
this book. That is, the book equates the removal of women's hijabs with the revelation of the grass roots on the grounds that the Islamic society sees women and the grass roots as the veiled indecent beings.

Despite the general viewpoint of this book, there is no denying that some passages seem to be recklessly biased towards women instead of seeking a macroscopic human liberation, e.g. the comments on the story of the queen of Sheba and the king Solomon in <Quran> and the comparison of capabilities between men and women. Specifically, in chapter 3, mentioning a Zaria called Shagab became the queen and appointed a female minister of law, the author remarks the queen perceived women were better at dealing with justice.

Is that the queen's perspective or does the author feel the same way? Also, when both a woman and a man committed murders for political causes, does it make sense to deem the suffocation or poisoning by the women as a less cold-blooded and more positive way of murdering people? Those passages make me wonder if the view of a gendered rivalry for superiority is that of a true feminist. Without doubt, women have felt resentment and antipathy against the lopsided men-oriented views. Still, men would feel the same way, should they be faced with an asymmetric women-oriented view. Arguably, the angle toward the issue should be moved from gender to humans. This is ultimately related to the role and significance of this book. Is this book to prove men-oriented Islamic leaders wrong by highlighting the fact that there were hidden female leaders and they well played their political roles in the Islamic society tilted towards male leaders? Is it to emphasize women can do as well as men?

The foregoing questions arise especially in chapter 3 that deals with the revolts of slaves in pursuit of equality. The slavery is universally recognized as an absurd system. Anyone knows it is not true that people became slaves because they were inferior. They may have been forced to become slaves due to temporary sociocultural conditions, or the law of the jungle must have driven them to forego their existence as humans. Why not see the gender issue from that perspective?

Anyone is aware that the reason women failed to become political leaders was not that they were inferior to men. Given the book's conclusion approaches the liberation of grass roots from the feminist perspective, it is unlikely that the book is intended to prove women are superior to men in light of the political power and choose to commit political murders in moderate ways. Retrieving some forgotten Islamic queens, this book does not underscore queens' superior political power to that of kings. Even though the book does mention the political superiority of a queen (chapter 9 allots a great deal of space to describe the insanity of Al-Hakim, who 
succeeded to the caliphate prior to his elder sister Queen Sitt al-Mulk), her superiority may be explained by her capacity as a person or the historical settings rather than the fact that she is a woman. The idea that women are better at dealing with justice or governing seamlessly is equivalent to the contestable view that women cannot deal with certain things because they are women, which is not different from the perspective of other male historians.

Concerning the story about Schuh, a caliph's wife defeated by her political rival and a man of power Ibn Amir, the author is reluctant to mention her lack of capacity(p.90) but should admit what a woman cannot do frankly. It is of course understandable that the author feels obliged to fight against the narrow perspective of a majority of male historians and cannot but side with female leaders, which however the author should overcome. Although quite a few male historians disparage the female leaders in the history of the Islamic world, it would be enough to uncover the fact that female leaders were great, since the statement that females outdid males is synonymous with the stance taken by numerous male historians. In brief, the angle need be moved from gender to mankind.

In that respect, the description in the last passage of chapter three that women were limited to their space (Harem) although they appeared to be at the center of power implies they were far from true leaders and leaves much to be desired. Though being obviously tuned in to female leaders of Islamic states, this book should add some paragraphs speaking highly of the noteworthy attitude of Zarias who as women and slaves went through and got over the adversities harsher than those of male slaves (Zanjis).

In some ways, the book may have been intended to emphasize how queens as women underwent the hardships and adversities in the men-centered Islamic society. Therefore, the last section of chapter 5 should be noted in that it gives attention to the ordinary aspects and humanity of Islamic female rulers, discarding the double standard that they should be great, superb and exceptional unlike men. Moreover, as the history says, the book sheds light on the presence of queens in the Islamic society and suggests the gender equality will come true in the society someday. That is the future that the wheel of history is destined for. The book desperately hopes for the future, implying it will come surely though slowly.

\section{Arabic language, Writing, Women and Grass-roots liberation}

Many key Arabic words show up from chapter 1. As the words persistently appear throughout the book, readers though not intending to learn Arabic language had better learn their meanings in the first place. Otherwise, they should go back to find out what they mean. 
Therefore, readers are advised to peruse the book from cover to cover without skipping any chapter. Readers who are used to skimming through chapters to find some main points or reading backwards from conclusions as I usually do will have to spend time and effort on figuring out the meanings of such Arabic words. Particularly, those who have no knowledgeability about, or are unfamiliar with, Islamic glossary or culture should heed my advice. Furthermore, as the chapters are not independent of but closely associated with each other, it is necessary to read the book sequentially from chapter 1 to properly understand the contexts of what the author means to say.

The author uses Arabic words, which are treated just like proper nouns in the Korean version with their pronunciations marked in Korean. For example, those words that have corresponding common nouns in Korean such as Sultan(king), Sultana(queen), Abd(slave) and Zaria(female slave) are consistently mentioned in Arabic pronunciations as if they were proper nouns with their etymology and contexts described in detail. In chapter 7 on Yemen's Shia dynasty, the etymology and concepts of 'Shia' are elucidated on several pages. This is indicative of the author's sincere interest in the language as well as the close link between the language and the world view of its users. On the other hand, the author illuminates the extent to which Arabic language involves gender and hierarchical discriminations probably in the hope of dismantling those words. That is, the author wants to trace back to their origins to reveal the true hidden intentions and delusions.

In chapter 1, the author explains 'hurr' (to be free), which implies resistance, and 'harara'(meaning to write) implying the liberation of words to make sense and of semantics. In chapter 2, the author explains 'umma' derived from 'umm'(mother) is a positive word implying a religious community, whereas 'amma'(people) means the unenlightened and uncultured masses that are incapable of self-reflection and discernment and must be excluded from the power. At this point, writing for freedom and liberation, the author integrates the feminine issues with the grass-roots. In addition, the key words keep showing up till the end of this book to constitute its main ideas.

'Hajaba' ('to conceal' and 'to separate') shares the etymology with 'hijab(veil)', which means 'a barrier'(p.323). 'A veil' is a sign of the absence of those deceased, which is the law of veils. Requiring women to wear veils(hijabs) and become the beings of absence indicates Arabic men absolutely oppose women's willingness to become masters. That is why queens such as Malika Asma would not wear veils while attending meetings. In the Arabic world coercing women into obeying men, a woman who refuses to do so is referred to as a 'al-nashiz,' whose plural form 'nushuz' means a 'chaos' and is surprisingly a synonym of 'people' manifest in the 
Universal Declaration of Human Rights (p.315).

Also, the author asserts religion veils the political dictatorship although the two are united together in the Islamic world (p.331). Caliphs think of the 'umma(ideal communities)' as being replete with 'amma(grass roots)' who are willing to kill them. Thus, people are regarded as beings that should be separated by veils from Caliphs like women. Given Caliphs' obligation is to protect believers, requiring women and people to be separated by veils and to be absent like the dead is highly contradictory. As the word 'Muslim' means 'to obey,' grass roots and women who are not religious leaders are allowed to neither disobey nor freely speak (p.331). By means of religion and politics, Caliphs and Mulk suppress women and grass roots and stick to the religion, whereas women and people can not. "People do not act in the same way as believers do(p.334)."

The author takes a linguistic approach while linking the status of women with that of grass roots in the Islamic world. That is, the author elucidates how the contradictory aspects of the Islamic world have been embodied by its language. The author perceives the attitude towards women in the Islamic world is not different from that towards grass roots, and faces squarely the true colors of the world from an outstanding and keen point of view, which is why readers should peruse the book while embracing the issues as ours, not theirs, as contemporary citizens. Again, readers should not complain about those Arabic words used like proper nouns without being translated into Korean. Rather, they should be attentive to how the suppression hidden behind those words is revealed, which will add to the fun, interest and significance of reading the book.

\section{Conclusion}

I have read the book from cover to cover. Still, some questions linger (why the kings preceding and succeeding the two queens did not share their power with their wives as the husbands of the latter did in chapter seven, and whether the democratic relationship of couples lasted around or after that point of time). Nevertheless, I would like to give the author a standing ovation and heartful respect for her insight that women's debut into the world of politics when they were supposed to live under the control of Caliphs was a sign of pawns thirsty for power entering the scene, which was construed as the demise of regimes(p.24). Finally, I feel extremely grateful to encounter the Korean version of such an invaluable book. 


\section{References}

[1] F. Mernissi, The Forgotten Queens of Islam, Sultanes Oubliees, France (1990)

[2] F. Mernissi, The Forgotten Queens of Islam, trans by Al-i-tar, Huud books, Seoul (2016)

[3] D. Cho, Interrelated issues in Korean, East Asian and world literature, Jimoondang, Seoul (2006)

[4] J. M. Kim, Islamic Feminism and Rereading Religious Texts from Women's Perspective, Korean Journal of Middle East Studies (2015), Vol.36, No.1, pp.71-101. 